\title{
Contribution Of Principals To School Disaster Management Preparedness In Public Secondary Schools In Kakamega County, Kenya
}

\author{
Pamela Ananda*, Prof. Enose M.W.Simatwa*, Dr. Stella Juma** \\ *Faculty of Education, Tom Mboya University, \\ **Faculty of Education, Rongo University \\ DOI: 10.29322/IJSRP.12.01.2022.p12163 \\ http://dx.doi.org/10.29322/IJSRP.12.01.2022.p12163
}

\begin{abstract}
Safety of students in schools is a matter of concern globally. In Kenya, students have lost their lives in the past four years due to arson, accidents, and food poisoning in spite of existence of Safety Standards Manual for schools. In Kakamega County there have been 65 deaths, 205 cases of food poisoning, 112 gang rape, 103 floods, 107 landslides, 50 fires, 102 lightening, 15 cyclones and 10 accidents in school buses for the years 2012 2016. This study therefore was to establish the contribution of principals to school disaster management preparedness on school grounds in public secondary schools in Kakamega County. The objective of this study was to establish the contribution of principals to disaster management preparedness on school grounds in public secondary schools in Kakamega County. The conceptual framework showing interrelationships between contribution of principals and disaster management preparedness was used to guide the study. Study population was 419 principals and 1 County Quality Assurance and Standards Officer. The sample size of 200 principals and 1 CQASO was used in the study. The study established that there was a positive relationship between contribution of principals to school disaster management preparedness. The findings of the study revealed that secondary schools in Kakamega County are faced with a variety of disasters with varying magnitude as signified by coefficients $0.713,0.663$, $0.771,0.727$ and 0.721 respectively at a significant level of 0.05 . The study concluded that principals contribution enhanced disaster management preparedness in secondary schools in Kakamega County. The study recommended that principals should make an effort in ensuring the school ground is secure based on the title deed, school registration, secured gates, day and night security, clean rooms, chairs desks and well maintained ground. The findings of this study are useful to stakeholders in education as they inform on the need to ensure safety policy manual is put in place to ensure safety objectives are achieved.
\end{abstract}

Index Terms- School ground, Title deed, Security personnel, Play grounds, Motorways, Walkways, Clean learning rooms

\section{INTRODUCTION}

$I^{n}$ n America, United States Department of Education (USDE) had to enforce strict safety policy in view of the threats posed by terrorism, drug related violence and natural disasters (USDE,
2004). Rising frequency, amplitude and number of natural disasters and attendant problems coupled with loss of human lives like the Mexico earthquake of 1985, prompted the general Assembly of the United Nation (UN) to proclaim 1990s as the International Decade for Natural Disaster Reduction (Alexander, 2002). The Columbine High school Massacre of 1999 where two senior students killed twelve students and one teacher and then committed suicide was one of the deadliest disasters in the United States of America (Brown, 1999).

International Strategy for Disaster Reduction (ISDR, 2010), earthquakes around the world, school buildings not built as per hazard resistant standards collapsed, causing severe setback to primary education. Examples of earthquakes are: Skopje, Yugoslavia in 1963, where 44 schools were destroyed (57 percent of school building stock); El Asnam, Algeria in 1989 where 80 schools collapsed or were severely damaged; Pereira, Colombia in 1999, whereby 74 percent of schools were damaged; Xinjiang, China in 2003, where dozens of schools collapsed; and Algeria in 2003, where 130 schools suffered extensive to complete damage (ISDR, 2010). The earthquake and subsequent tsunami on $26^{\text {th }}$ December 2004 devastated communities and schools in coastal regions, primarily in Indonesia, the Maldives, Sri Lanka, India and Thailand (UNESCO, 2007). Following the October 2005 earthquake in Northern Pakistan, between 17,000 and 20,000 students were reportedly killed in the collapse of some 10,000 school buildings (Asian Disaster Preparedness Center, 2008). Children comprised half of more than 75,000 deaths. Over 1,000 health care facilities were also destroyed, with high casualties among patients and health care workers. In the Gujarat 2001 earthquake 11,600 schools were destroyed or severely damaged. The main shock occurred during a national holiday where tragic incidents involving students in schools for celebrations comprised half of more than 20,000 dead (ADPC, 2008).

Among the various natural disasters are the deadliest and costliest, which are also a matter of fact, each time a disaster occurs, masses of school children are victimized and many of them never return. In 1988 Spitak Earthquake (Armenia) killed more than 17,000 students while in schools, which was $2 / 3$ of total earthquake fatality. Likewise, in 2001, 971 students and 31 teachers were killed by Bhuj Earthquake in India. In 2004, a fire tragedy due to explosion of a cooking gas cylinder in Tamil Nadu (India) killed 93 school children. Most terrible disaster in school 
were recorded in 2005 after Kashmir Earthquake (Northern Pakistan), which killed 17,000 students in different schools while 50,000 more were seriously injured. In 2006, an elementary school in Philippines was buried in a landslide and 245 children and teachers were killed. Moreover, in 2008, more than 10,000 children were killed during the Sichuwan Earthquake in China.

In Pakistan, over 5,500 schools were damaged across the country, while 5,000 others are being used as shelters for displaced families. 8.6 Million Children under 18 years are affected (Muzaffargarh, 2010). Lightning is the most under recognized weather hazard. It is a leading cause of storm deaths and also inflicts life-long severe injuries on many more (Cooper, 1995).

AMREF (2005) states, sanitation is viewed as a base for promoting public health. Burger (2000) asserts, globally 2.3 million people live with no access to sanitary facilities and are unable to practice basics such as washing hands with soap and water. Rocha (2001) in Peru recommended provision of free or subsidized sanitary napkins at school level to facilitate sanitary conditions that protect girls from humiliation in school. The study focused on lack of bathroom facilities, water and sanitary supplies in Peru schools. Veerashekharappa (2005) in his study in India, asserted that, sanitation services in schools is poor, making it become unsafe places where diseases are transmitted. A study in Pakistan, found out that at Noor Purshahan Girls Secondary school, there was acute shortage of drinking water (Republic of Pakistan, 2003), which led to airborne diseases. World Health Organization (2009) states that, schools with poor water, sanitation and hygiene conditions expose students to disease risks and enhanced susceptibility to environmental health hazards. United Nations International Children Education Fund (2007) states that, more than 60 percent of all schools in Africa lack sufficient water and sanitation facilities.

The Fire Administration National Data Centre (FANDC) reported that South America, Asia and Africa, have recorded large death toll related to school fires due to lack of preparedness (FANDC, 2007). In July 2004, fire tragedy killed 90 learners in an Indian school because of lack of emergency doors and firefighting equipment. Due to failure to implement safety norms the school buildings in this case were overcrowded and hard no exit. There were no emergency doors and firefighting facilities. Fire disasters in Indian schools are blamed on failure by authorities to enforce safety regulations. For instance, schools may stay for as long as three years without being inspected (Reuters, 2004). According to the Safety Standards Manual (R.O.K, 2008), schools' physical infrastructure should comply with the provisions of the Education Act (Cap 211), Public Health Act (Cap 242) and ministry of public works building regulations/standards. Wedgewood (2005) in his study in Tanzania, states that, latrines are important facilities for maintaining attendance especially for girls.

In Africa, violent incidences have been reported mostly in South African black township schools and in the killings and destruction (NACADA, 2002). These disasters include drought, floods, fires, landslides, transportation accidents, terrorist attacks and the post- election violence to mention but a few. Oranusi et al (2007) in a study on food safety evaluation in boarding schools in Ziaria, Nigeria, using Hazard Analysis Critical Control Plan (HACCP) system found out that water for drinking and cooking was from dirty tap water environments, uncovered wells and boreholes. FAO/WHO (2005), reported in a conference on food safety for Africa that some vendors in Acacia, Harare, Lilongwe and Lusaka washed their hands in the same bucket used for washing utensils, which may lead to contamination.

Kenya is one of the most vulnerable developing countries to suffer very often from various natural as well as technological (human made) disasters which strike causing a devastating impact on human life, economy and environment (Alexander, 2002). The Kenya Red Cross Society Observes that secondary schools are vulnerable to disasters because of lack of specialized training such as fire drills, lack of appropriate firefighting equipment, lack of adequate resources, lack of systematic disaster contribution and response mechanisms (GOK, 2008). According to USFADC (2007), fire drills are the largest contributing factor to the safety of students in school. Most fires in schools result from faulty electrical installations (USFADC, 2007). Research study conducted by Akali, Khabamba and Muyinga (2011) reveals that, there is little done to prepare secondary schools in Kenya for fires. He postulated that, only a handful of secondary schools have firefighting extinguishers in office, laboratories, stores and kitchen. Synthesis of literature on contribution of principals to school disaster management preparedness on school grounds in public secondary schools.

The United States Department of Education (USDE, 2004) requires safety policies in schools to be strictly enforced in view of the threats posed by terrorism drug related violence. Proliferation of firearms and natural disasters like typhoons floods and hurricanes. Most American public schools have zero-tolerance policies on activities that are likely to compromise safety. A school survey on crime and safety report states that in the 1996/1997 school year, 90\% of the schools reported zerotolerance policies for firearms. In the same period of time, schools implemented a number of approaches to enhance safety and security. $96 \%$ of public schools required visitors to sign in before entering into the school plant. $80 \%$ of public schools had a closed 26 school policy that prohibited students from leaving school premises except at specified times. Six percent of schools had policemen or other law enforcement personnel stationed thirty hours a week or more at the school in a typical week (United States Department of Education, 2004).

In 2008, fire at Buddo Primary School, Uganda, left 19 girls and two adults dead. The affected lacked provisions for a house mother. The doors were locked from outside. Investigations revealed that classrooms had been converted into dormitories without consulting the district engineer and the health officers as required by the law (Hirano, 2009). After the tragedy, Uganda implemented the Safe School Contact as a remedy which strengthens the role of stakeholders such as teachers, learners and parents in disaster risk reduction. A study in Ugandan schools by Nakitto and Lett (2012) where 50 schools were randomly chosen concluded that, 84 percent of schools had no fire safety plans in place. According to the International Strategy for Disaster Reduction (ISDR, 2010), in many earthquakes around the world, school buildings which were not built as per hazard resistant standards collapsed, causing severe setback to primary education. The 1991 raid by boys on the girls' dormitory at St. Kizito Secondary School in Meru resulted in the death of 19 girls (Simatwa, 2007). In 1993, armed gangsters stormed Hawinga Girls Secondary School. The school had no perimeter fencing making it easier for the gangsters to access the school and rape 
students (Oriang, 2001). Gicheru (1998) states that overcrowding was one of the factors that contributed to the death of 27 girls in the 1998 Bombolulu Girls dormitory fire. Odalo (2001) stated that the absence of firefighting equipment and emergency exits led to the high death toll during the Kyanguli Secondary School fire. Sixty-eight boys lost their lives in this incident. The schools were ordered to remove grilles from dormitory windows to protect students during disasters. It was recommended that school managers should beef up security by employing an adequate number of watchmen (Savula \&Atsiaya, 2004).

\section{RESEARCH OBJECTIVE}

To establish the contribution of principals to school disaster management preparedness on school grounds in public secondary schools.

\section{CONCEPTUAL FRAMEWORK}

This study was based on a conceptual framework which explains the basis of a given study. According to this model there is a relationship between contribution of principals and disaster management. Conceptual framework postulates that contribution of principals impacts positively on disaster management preparedness. The independent variable was contribution of principals while the dependent variable was disaster management preparedness. The available literature was used to formulate the conceptual framework (Leeds \& Ormrod, 2005) and it also helped in focusing on the variables of the study.

The conceptual framework in Figure 1, postulates that disaster management in schools depends on principals contribution.

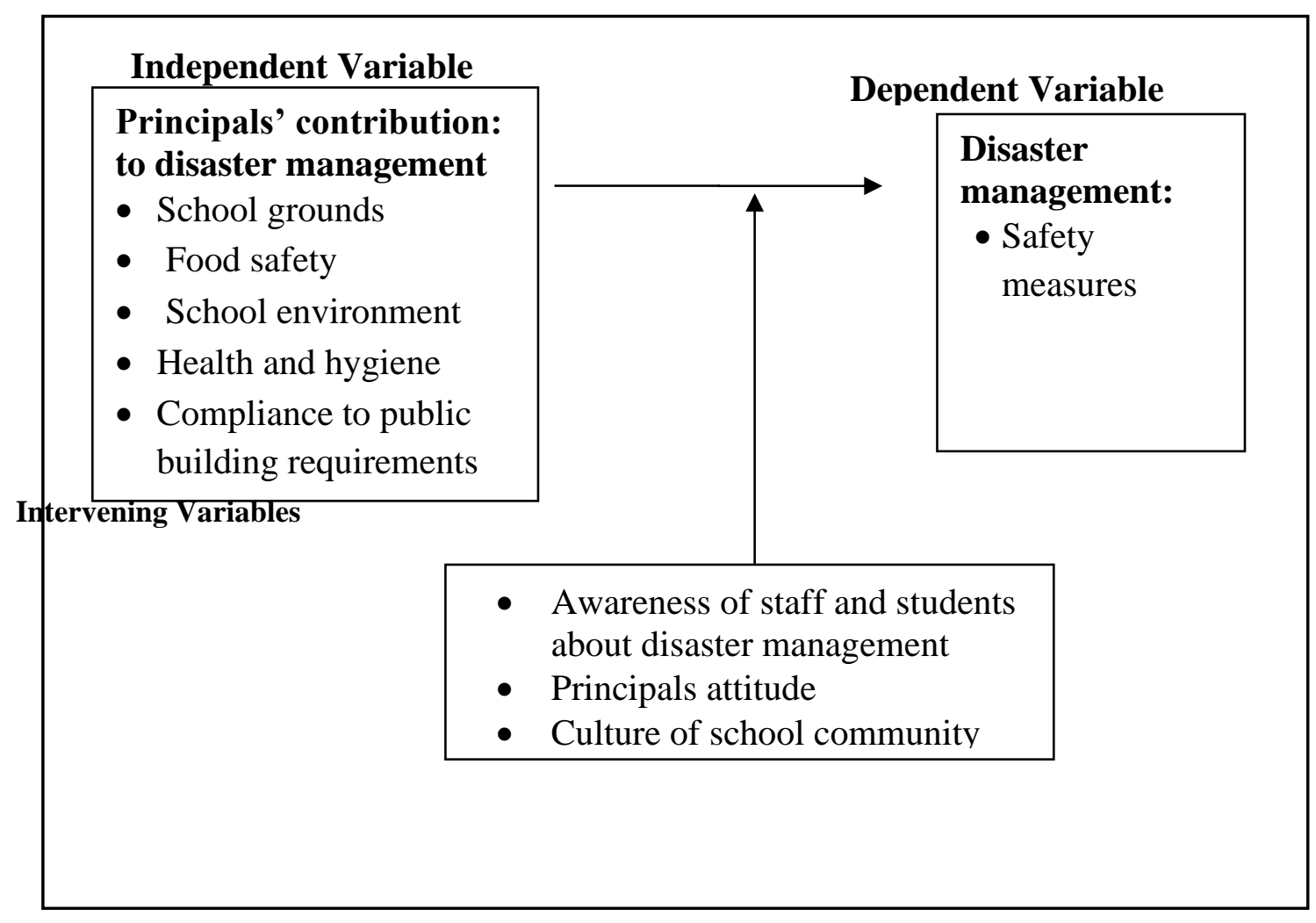

Figure 1: A Conceptual Framework Showing Contribution of Principals to school Disaster Management Preparedness in Public Secondary Schools in Kakamega County Source: Researcher

The conceptual framework was adapted to focus on the independent and dependent variables. Independent variable was contribution of principals while dependent variable was disaster management preparedness. According to McBurney and White (2010) an independent variable is chosen by a researcher to determine the effect and behavior while dependent variable is a measure. The principals need to ensure that the staff and students are made aware of how to manage disasters in schools through workshops, seminars and drills. Information needs to be availed to them. Principals need a supportive community to be able to implement safety policies in schools. Communities with positive attitude towards the school become protective over them and such schools rarely experience cases of insecurity (Otula, 2007).

\section{RESEARCH METHODOLOGY}

A correlational research design was used. Kakamega County was used as the site for the study. The study population was 419 principals and 1 CQASO. Fishers' formular (Mugenda \& Mugenda, 2003) was used to determine the sample size. Questionnaires, interview schedule and observation checklist were 
used to collect data. Face and content validity of questionnaires were determined by experts in educational policy and management. Reliability of questionnaires was determined through test-retest technique. Pearson's ' $r$ ' coefficients for principals contribution questionnaire was 0.81 and 0.88 respectively at a set $\mathrm{P}$ - value of 0.05 , meaning they were reliable. Quantitative data was collected using closed items of questionnaires and document analysis guide. Qualitative data were transcribed, analyzed and reported in emergent themes and subthemes.

\section{RESULTS}

\section{Research Question}

The research question responded to was: to determine contribution of principals to disaster management preparedness on school grounds in public secondary schools based on: Acquisition of title deed, registration of the school, secured gates, provision for day and night security, maintained and cleaned learning rooms, clean chairs and desks in classrooms and offices, maintained playgrounds, maintained walkway, motorways and parking. To address the question the study undertook regression analysis to get actual contribution of principals to disaster management preparedness as shown below. A correlation research was used to give the degree to which they are related by use of a correlation coefficient. The mean ratings and status to this research question by principals were as shown in Table 1 and 2

Table 1: Principals Ratings on their Contributions to School Disaster Management Preparedness on School Grounds

\begin{tabular}{lll}
\hline Mean Ratings & Frequency $\mathbf{f}$ & Percentage $\%$ \\
\hline $1.00-1.44$ & 10 & 5.55 \\
$1.45-244$ & 6 & 3.33 \\
$2.45-3.44$ & 40 & 22.22 \\
$3.45-4.44$ & 124 & 68.88 \\
$4.45-5.00$ & 0 & 0 \\
Total & $\mathbf{1 8 0}$ & $\mathbf{1 0 0}$ \\
\hline
\end{tabular}

Source: Field Data, 2018 -2019

Interpretation:

$1.00-1.44$ Very Low (VL)
$1.45-2.44$ Low $(\mathrm{L})$

$2.45-3.44$ Moderate $(\mathrm{M})$

$3.45-4.44$ High $(\mathrm{H})$

$4.45-5.00$ Very High (VH)

From Table 1 it is indicated that in 124(68.88\%) schools there was very high disaster management preparedness while in $40(22.22 \%)$ schools preparedness was moderate. $6(3.33 \%)$ of the schools had contributed low on school ground preparedness while 10(5.55) had nothing in place to show disaster management preparedness on school grounds.

Table 2: Status of School Grounds

\begin{tabular}{lll}
\hline Mean Ratings & Frequency f & Percentage $\%$ \\
\hline $1.00-1.44$ & 10 & 5.55 \\
$1.45-244$ & 6 & 3.33 \\
$2.45-3.44$ & 41 & 22.77 \\
$3.45-4.44$ & 123 & 68.33 \\
$4.45-5.00$ & 0 & 0 \\
Total & $\mathbf{1 8 0}$ & $\mathbf{1 0 0}$ \\
\hline
\end{tabular}

Source: Field Data, 2018 -2019

Interpretation:

$1.00-1.44$ Very Low (VL)

$1.45-2.44$ Low (L)

2.45 - 3.44 Moderate $(\mathrm{M})$

$3.45-4.44$ High $(\mathrm{H})$

$4.45-5.00$ Very High (VH)

Table 2 shows that, the level of preparedness in $123(68.33 \%)$ schools was very high, in $41(22.77 \%)$ the level was moderate , 6(3.33) schools had a low level of preparation where students were exposed to very many disasters. In 10(5.55) schools the level of preparation was very low as regards safety on school grounds.

To determine the contribution of principals to disaster management preparedness to school ground regression analyses were computed and the results were as shown in Table 3

Table 3: Contribution of Principals to Disaster Management Preparedness on School Grounds: Model Summary

\begin{tabular}{|c|c|c|}
\hline Aspects of Contribution & Adjusted R Square & Sig. F \\
\hline Acquisition of title deed & .401 & .000 \\
\hline Registration of the school & .082 & .000 \\
\hline $\begin{array}{l}\text { Lockable gates or gates with a } \\
\text { security officer }\end{array}$ & .666 & .000 \\
\hline $\begin{array}{l}\text { Provision for both night and day } \\
\text { security personnel }\end{array}$ & .481 & .000 \\
\hline $\begin{array}{l}\text { Well maintained and clean learning } \\
\text { rooms }\end{array}$ & .545 & .000 \\
\hline $\begin{array}{l}\text { Clean chairs and desks in } \\
\text { classrooms and office }\end{array}$ & .603 & .000 \\
\hline Properly maintained play grounds & .404 & .000 \\
\hline $\begin{array}{l}\text { Properly arranged and maintained } \\
\text { walkways, motorways and parking }\end{array}$ & .536 & .000 \\
\hline
\end{tabular}


Table 3 indicates that principals contributed to disaster management preparedness through acquiring title deed. The contribution was $40.1 \%$ as signified by adjusted $\mathrm{R}$ square coefficient .401 . It can also be noted that principals contributions in terms of acquisition of title deed is a significant indicator to disaster management preparedness.

County Quality Assurance Standards Officer (CQASO) said this from the interview: "Once our schools have title deeds it will give an assurance of ownership which will give the school community confidence to develop". Title deed can be used to win funding for development of the school also for the total acreage to be known before planning. CQASO in the interview said, "The reason why we encourage all schools to ensure they are registered is for security purpose to both the students and any other member in the school and also it gives identity to the school". He continued to say that, "In the recent we have had intruders in schools causing harm to students and to even teachers, secure gates will ensure security in the school". If a principal takes the responsibility of ensuring all playgrounds are well maintained, this will help in warding off injuries. Most principals don't remember to ensure there's a designated area for parking, motorways and even walkways; it's a risk to the school community. The school ground needs to be secured in total to minimize disasters in schools.

These findings agree with United States Department of Education (2004) that schools need safety policies on school grounds due to threats posed by terrorism and drug related violence. Cavanagh (2004), states that since the 1993 school hostage crisis in the French city of Neuilly, policy coordinate security on school grounds. Safety on school grounds is essential for safety of all students in the school. The findings on safety on school grounds disagrees with a study carried out in Kajiado District by Muigai (2011) he states that not all teachers and principals had attended any course, seminar and workshop on school safety, a few of them were aware of safety precautions to avert disasters. The findings further disagree with Okumu (2014) in his study in Kisumu West District that a few principals had great opportunities to implement school ground safety.

A study on disaster awareness and preparedness of secondary schools in Homa Bay County, by Onyango (2011) where his study revealed that secondary schools in Homa Bay County are faced with various disasters most of which are floods-related as stated by $85.4 \%$ of principals. Onyango (2011) findings showed that most secondary schools in Homa Bay County were not adequately prepared to deal with disasters. Okumu (2014) focus was on implementation of selected safety policy guidelines. Ngecu and Mathu (1999), study in Kenya established that, heavy rainfall resulted in floods and landslides in various parts of the country as well as loss of lives. Oriang (2001) in his study in Hawinga Girls secondary school established the school had no perimeter fencing making it easier for the gangsters to access the school and rape students. Gicheru (1998) states that one of the factors that contributed to the death of 27 girls in the 1998 Bombolulu Girls dormitory fire was overcrowding. Odalo (2001) stated that the high death toll during the Kyanguli Secondary School fire was caused by absence of firefighting equipment and emergency exits.
Table 3 indicates that principals contributed to disaster management preparedness through registration of the school. The contribution was $8.2 \%$ as signified by adjusted $\mathrm{R}$ square coefficient .082. It can be noted that principals contribution in terms of registration of the school is a significant indicator to disaster management preparedness. To avoid court cases with neighbors who might claim ownership of the land, schools are to be registered and a code will be given where all its activities are performed in school. The findings agree with Republic of China (2011) where more than 300 students at Changzhou City got food poisoning after lunch and it was later discovered that this was due to unsanitary conditions at school. Park, Kwak and Chang (2010), in their study on evaluation of food safety training for food handlers operations in Korea, 510 food borne disease outbreaks with 9,686 patients were reported with 93 of them being attributed to institutional food service operations. Food safety evaluation in Zaria, Nigeria using the Hazard Analysis Critical Control Plan (HACCP) system, found out that water for drinking and cooking was from dirty tap water environments, uncovered wells and boreholes Oranusi et, al (2007).

Republic of Kenya, (2008) that food safety is access and consumption of wholesome food that promotes good health and optimal body functioning. Ooro (2008) showed that, learners who have access to wholesome food have more enjoyable and successful learning experience. Food borne illness outbreaks originating in the cafeteria can be prevented by appropriate knowledge and adequately trained foodservice (FSP, 2005). Shaw (2002) in a study on international experiences and actions in promoting school safety states that new collections of exemplary, good or promising practices have been published.

Maritim (2014) in her study on school safety and emergency preparedness: an assessment of public boarding secondary schools in Nandi North District. Findings revealed that most schools were inadequately prepared for emergencies both in terms of planning and equipment. Maritim's (2014) findings showed that most schools were inadequately prepared for emergencies both in terms of planning and equipment.

Table 3 indicates that Principals contributed to disaster management preparedness in terms of secure gates with a security officer. The contribution was $66.6 \%$ as signified by adjusted $\mathrm{R}$ square coefficient .666 . It was noted that principals contribution to disaster management preparedness in terms of secure gates with security officer is significant indicator to disaster management preparedness. Monitoring of who comes in and who goes out is very important in a school for security reasons, those carrying weapons or drugs can be easily detected. It helps in identifying strangers from students and staff. Students are used to being monitored because of sneaking out of school, with security at the gate, it becomes easy for teachers to ensure the students are in the compound throughout. It also helps to curb theft cases among students and workers who are leaving to their homes. Movement of students in and out of school can be easily monitored at a secure gate with security personnel.

These findings agree with, the dawn of 21 st century in Kenya which saw an increase in insecurity in secondary schools where students exhibited excessive unbecoming conducts 
(MOEST, 2001). In 2007 alone 300 secondary schools were closed after students went on the rampage destroying property and a number of them lost their lives (Kindiki, 2009). Safety in Kenya secondary schools is guided mainly by a ministry circular ref G9/1/169/2001 and a safety standards manual for issues published in 2008. These two instruments were issued out of the conviction that safe and secure school environment facilitates and fosters quality teaching and learning. Safety is more critical given the fact that young children are vulnerable to insecurity /safety standards (Republic of Kenya, 2008).

Table 3 indicated that, Principals contributed to disaster management preparedness in terms of provision of both day and night security personnel. The contribution was $48.1 \%$ as signified by adjusted $\mathrm{R}$ square coefficient .481 . From Table 3 it can be noted that principals contribution to disaster management preparedness in terms of provision of both day and night security personnel are significant indicators to disaster management preparedness. Monitoring of who comes in and who goes out is very important in a school for security reasons, those carrying weapons or drugs can be easily detected. It helps in identifying strangers from students and staff. Students are used to being monitored because of sneaking out of school, with security at the gate, it easier for teachers to ensure the students are in the compound throughout. It also helps to curb theft cases among students and workers who are leaving to their homes. Movement of students in and out of school can be easily monitored at a secure gate with security personnel.

In the $21^{\text {st }}$ century in Kenya findings saw an increase in insecurity in secondary schools where students exhibited excessive unbecoming conducts (MOEST, 2001). 300 secondary schools were closed in 2007 after students went on the rampage destroying property and a number of them lost their lives (Kindiki, 2009). Safety in Kenya secondary schools is guided mainly by a ministry circular ref G9/1/169/2001 and a safety standards manual for issues published in 2008. These two instruments were issued out of the conviction that safe and secure school environment facilitates and fosters quality teaching and learning (Republic of Kenya, 2008). Shows that, Safety is more critical given the fact that young children are vulnerable to insecurity /safety standards. Simatwa, (2007) states in 1991 raid by boys on the girls' dormitory at St. Kizito Secondary School in Meru resulted in the death of 19 girls Oriang, (2001) findings state that, in 1993, armed gangsters stormed Hawinga Girls Secondary School. The school had no perimeter fencing making it easier for the gangsters to access the school and rape students. Overcrowding was one of the factors that contributed to the death of 27 girls in the 1998 Bombolulu Girls dormitory fire, Gicheru (1998).

Principals contributed to disaster management preparedness in terms of well-maintained and clean learning rooms. The contribution was $54.5 \%$ as signified by adjusted $\mathrm{R}$ square coefficient .545. When students are healthy they will attend classes without being absent for being sick. It becomes important for principals to ensure standards of cleanliness are maintained in schools. Principals contributed to disaster management preparedness in terms of clean chairs and desks in classrooms and offices. The contribution was $60.3 \%$ as signified by adjusted R square coefficient .603. From Table 3 it can be noted that principals contribution to disaster management in terms of clean chairs and desks in classrooms and offices are significant indicators to disaster management preparedness. When students are healthy they will attend classes without being absent for being sick. It becomes important for principals to ensure standards of cleanliness are maintained in schools.

These findings agree with AMREF (2005) that, sanitation is viewed as a base for promoting public health. Burger (2000) asserts, globally 2.3 million people live with no access to sanitary facilities and are unable to practice basic such as washing hands with soap and water. Safety Standards Manual for Schools in Kenya (2008), classrooms should at all times do the following to prevent fire: all kinds of trash should be discarded as they tend to quickly catch fire, inflammable substances such as petroleum, paint, chemicals should be stored in tightly closed cans or containers and away from any source of heat. According to Adan (2012) reducing cholera, Amoebiasis, diarrhea and worm infestation in schools can be done by maintaining good hygiene and sanitation practices. WHO (2009), states that, improved health status translates into regular school attendance and higher academic performance. A conducive environment for learning and for developing useful life skills on health and hygiene should be initiated by the school (Adan, 2012). Omolo (2011) assessment on implementation of safety policies in public schools found out that sources of school water were important aspects of school safety. Health of people and dignified life are based on access to safe water and proper sanitation (UNICEF, 2000).

Principals contributed to disaster management preparedness in terms of properly maintained playgrounds. The contribution was $40.4 \%$ as signified by adjusted R square coefficient .404 . From Table 3 it can be noted that principals contribution to disaster management in terms of properly maintained play grounds are significant indicators to disaster management preparedness. This model can be used to predict the influence of the factors (maintained play grounds) on disaster management preparedness. To avoid accidents while students are playing in the field it has to be maintained to ensure it is free from any item that might cause injury. To encourage them to play, the field needs to be maintained always. Safety of students in the playground while using balls ropes and any other object remains a duty of the principals who liaises with the teachers, everything in the field has to be maintained.

These findings agree with International Strategy for Disaster Reduction (ISDR, 2010), in many earthquakes around the world, school buildings which were not built as per hazard resistant standards collapsed, causing severe setback to primary education. Republic of China (2011), states more than 300 students at Changzhou City got food poisoning after lunch and it was established this was due to unsanitary conditions at school. In literature such as the UNESCO (2007) and (ISDR) report (2008), Fothergill and Peek (2004), Paton and Johnston (2001) and Hosseini and lzadkhah (2006) there is strong evidence that the more prepared and knowledgeable a community is, the more resilient it becomes to disaster. Shaw et al., (2004), Hosseini and Izadkhah (2006) and Ozmen (2006) maintain that school education is important to ensure that learners respond 
appropriately when they are faced with a disastrous event. King (2000) observes that by raising awareness of expected hazards and increasing both knowledge of and active participation in appropriate preparations, it can be hoped that people will respond more effectively to warnings and behave safely when a disaster does occur. National governments have been seen to change their school curricula to include learning outcomes on hazards and disasters, like in the USA because of fears of terrorist attacks (Ozmen, 2006) and in Japan after the country had experienced a number of earthquakes (Shaw et al., 2004). Chile and Thailand also responded by amending their curriculum to integrate the teaching of hazard awareness and disaster preparedness.

Table 3 indicates principals contributed to disaster management preparedness in terms of $53.6 \%$ as signified by adjusted R square coefficient .536. From Table 4 it can be noted that principals contribution to properly arranged and maintained walkways, motorways and parking are significant indicators to disaster management preparedness. Table 4 shows that principals contribution to disaster management preparedness in terms of school grounds are significant indicators to disaster management preparedness.

Table 4: Multiple Regression Analysis of the Contribution of Principals to Disaster Management Preparedness on School Grounds Coefficients ${ }^{\mathrm{a}}$

\begin{tabular}{|c|c|c|c|c|c|}
\hline \multirow[t]{2}{*}{ Model } & \multicolumn{2}{|c|}{$\begin{array}{l}\text { Unstandardized } \\
\text { Coefficients }\end{array}$} & \multirow{2}{*}{$\begin{array}{l}\text { Standardized } \\
\text { Coefficients } \\
\text { Beta } \\
\end{array}$} & \multirow[t]{2}{*}{$\mathbf{T}$} & \multirow[t]{2}{*}{ Sig. } \\
\hline & B & Std. Error & & & \\
\hline \multirow{11}{*}{1} & (Constant) & .185 & & 3.500 & .001 \\
\hline & $\begin{array}{l}\text { Acquisition of Title } \\
\text { Deed (X1) }\end{array}$ & .042 & .022 & .429 & .669 \\
\hline & $\begin{array}{ll}\text { Registration } & \text { of } \\
\text { School (X2) } & \end{array}$ & .039 & .107 & 2.042 & .043 \\
\hline & $\begin{array}{l}\text { Lockable Gates (X3) } .120 \\
\text { Provision for both }\end{array}$ & .024 & .296 & 5.083 & .000 \\
\hline & $\begin{array}{ll}\text { Day and } & \text { Night } \\
\text { Security } & \end{array}$ & .034 & .371 & 5.566 & .000 \\
\hline & Personnel(X4) & & & & \\
\hline & Well Maintained and & & & & \\
\hline & $\begin{array}{l}\text { Clean(X5) Learning.027 } \\
\text { Rooms }\end{array}$ & .023 & .058 & 1.171 & .243 \\
\hline & $\begin{array}{l}\text { Clean Chairs and } \\
\text { Desks(X6) }\end{array}$ & .034 & .210 & 3.638 & .000 \\
\hline & $\begin{array}{l}\text { Properly Maintained } \\
\text { Playgrounds }(X 7)\end{array}$ & .033 & .078 & 1.555 & .122 \\
\hline & $\begin{array}{l}\text { Walkways,Motorway } \\
\text { s and Parking }(\mathrm{X} 8)\end{array}$ & .041 & .158 & 2.869 & .005 \\
\hline
\end{tabular}

a. Dependent Variable: Disaster Management Preparedness

For every one unit increase in principals contribution to registration of school to disaster management preparedness increases by .081 units. Registration of the school motivates the need to guard against any factors that would jeopardize the school. It also encourages students safety and gives identity to the school. As regards secure gates with a security personnel, for every one unit increase in principals contribution it enhanced .120 units. Secure gates in place with security personnel helps to provide safety. Unauthorized persons will not be allowed in school. Provision for both day and night security, for every one unit increase in principals contribution it enhanced disaster preparedness in schools by .188 units. This involved ensuring that safety measures were maintained at night and during the day. The principal facilitates this by employment of the security officers.
With regards to clean chairs and desks one unit increase in principals contribution enhanced disaster preparedness in schools by .124 units. It involved ensuring that classrooms are regularly painted and renovated accordingly. These wards off cases of infectious diseases or ailments associated with low level of hygiene. Contribution of principals is not significant because the duty is assigned to teachers on duty and the school prefects.

For every one unit increase in principals contribution to properly arranged and maintained walkways, motorways and parking to disaster preparedness it increases by .117 units. Such that there were no injuries from poorly maintained walkways, motorways and parking. Principals ensured maintenance was budgeted for, they designated areas as required. Overally the principals contributed $71.3 \%$ as earlier indicated. When regressed 
together there seem not be much in acquisition of title deed. Principals might not have done much on it. On well maintained and clean learning rooms, the focus on it might have been left upon the class teachers. Most classes are not painted regularly and most principals are not involved in cleaning classrooms. Play grounds take too long to be worked on by the principals, they remain in a bad state for long due to lack of funds. Principals contribution may not be signified.

King (2000) observes that by raising awareness of expected
hazards knowledge of and active participation in appropriate preparations, it can be hoped that people will respond more effectively to warnings and behave safely when a disaster does occur. National governments have been seen to change their school curricula to include learning outcomes on hazards and disasters, like in the USA because of fears of terrorist attacks (Ozmen, 2006) and in Japan after the country had experienced a number of earthquakes (Shaw et al. 2004). Chile and Thailand also responded by amending their curriculum to integrate the teaching of hazard awareness and disaster preparedness.

\section{DISCUSSION}

Principals contribution to disaster management in schools is very important because they are the administrators and have the responsibility to ensure safety of students. Their contribution accounted for $71.3 \%$ of disaster management as signified by 0.713 . Other factors were responsible for $28.7 \%$ of the variance. Principals contribution was found to be significant predictor of disaster management preparedness on school ground however, the contributions were found to have influence on school disaster management preparedness as revealed by regression analysis. The contribution considered title deed, registration of the school, lockable gates with a security officer, provision of both night and day security personnel and properly arranged and maintained walkways, motorways and parking. It was established that no principal contribution influenced preparedness of disaster management on its own as was signified by $\mathrm{r}=0.401, \mathrm{P}<0.05$ for title deed, $\mathrm{r}=0.082, \mathrm{P}<0.05$ for registration of school, $\mathrm{r}=0.666, \mathrm{P}$ $<0.05$ for secure gates and security officer, $r=0.481, \mathrm{P}<0.05$ for night and day security, $\mathrm{r}=0.545, \mathrm{P}<0.05$ for well maintained and clean classrooms, $r=0.603, P<0.05$ for clean chairs and desks, $r$ $=0.404, \mathrm{P}<0.05$ for maintained playgrounds, $\mathrm{r}=0.536, \mathrm{P}<0.05$ for maintained walkways, motorways and parking. The other percentages could be explained by other factors. The County Quality Assurance and Standards Officer had the view that principals contribution is vital to students safety.

Students safety in schools lies upon all stakeholders represented by the principal who is to ensure all is done and put in place according to the secondary schools safety manual to secondary schools.

Republic of China (2011), states more than 300 students at Changzhou City got food poisoning after lunch and it was established this was due to unsanitary conditions at school. Schools where demarcation is not done, anyone can get in and sell to students anything from drugs to dirty food. King (2000) observes that by raising awareness of expected hazards and increasing both knowledge of and active participation in appropriate preparations, it can be hoped that people will respond more effectively to warnings and behave safely when a disaster does occur. National governments have been seen to change their school curricula to include learning outcomes on hazards and disasters, like in the USA because of fears of terrorist attacks (Ozmen, 2006) and in Japan after the country had experienced a number of earthquakes (Shaw et al., 2004). Chile and Thailand also responded by amending their curriculum to integrate the teaching of hazard awareness and disaster preparedness. AMREF (2005) states that, sanitation is viewed as a base for promoting public health. Burger (2000) asserts, globally 2.3 million people live with no access to sanitary facilities and are unable to practice basic such as washing hands with soap and water. Safety Standards Manual for Schools in Kenya (2008), classrooms should at all times do the following to prevent fire: all kinds of trash should be discarded as they tend to quickly catch fire, inflammable substances such as petroleum, paint, chemicals should be stored in tightly closed cans or containers and away from any source of heat. According to Adan (2012) reducing cholera, Amoebiasis, diarrhea and worm infestation in schools can be done by maintaining good hygiene and sanitation practices. WHO (2009), states that, improved health status translates into regular school attendance and higher academic performance. A conducive environment for learning and for developing useful life skills on health and hygiene should be initiated by the school (Adan, 2012). Omolo (2011) assessment on implementation of safety policies in public schools found out that sources of school water were important aspects of school safety. Health of people and dignified life are based on access to safe water and proper sanitation (UNICEF, 2000).

Monitoring of who comes in and who goes out is very important in a school for security reasons, those carrying weapons or drugs can be easily detected. It helps in identifying strangers from students and staff. Students are used to being monitored because of sneaking out of school, with security at the gate, it becomes easy for teachers to ensure the students are in the compound throughout. It also helps to curb theft cases among students and workers who are leaving to their homes. Movement of students in and out of school can be easily monitored at a secure gate with security personnel.

\section{CONCLUSION}

From the findings it was concluded that principals need to ensure the school grounds are secure for easy running of the school, to avoid court cases with neighbors who might claim ownership of the land, and to ensure all its activities are performed in school. Consequently, a secure school ground will be beneficial to the school and the whole community. It will also ensure safety for the students while in school

\section{RECOMMENDATION}

\section{The study made the following recommendations:}


Principals should make an effort in ensuring the school ground is secure for students based on the title deed, school registration, secured gates, day and night security, clean rooms, chairs desks and well maintained ground.

The government to ensure the secondary school safety manual is implemented fully in schools.

Principals of secondary schools should encourage the school community to take interest in disaster management preparedness in school.

\section{REFERENCES}

[1] Achoka, J.S.K. (2007). Kenya's Management of Secondary School Education in the 21st Century: New Model for excekebee. J-Stem.

[2] Adan, A.I. (2012). Factors Influencing Provision of Water and Sanitation in Primary Schools in Kaloleni Division, Kilifi District. Unpublished Masters Thesis, Maseno University.

[3] Adinku, S. (1999). Disaster Management in the Balme Library. Unpublished Thesis University of Ghana.

[4] Akali, N.M., Khabamba, I. \& Muyinga, G.A. (2013). Fire sources, disaster impacts and mitigation in Kenya Secondary Schools. [Online]. Retrieved from: International Journal of Disaster Management and Risk Reduction. 3(3). http://irpsonline.com. sg [2013, May 10].

[5] Akech, B.A.O. \& Simatwa, E.M.W. (2010). Opportunities and Challenges for head teachers of public primary schools in the implementation of Free Primary Education in Kisumu Municipality, Kenya: An analytical assessment. Retrieved on $3 / 11 / 017$ at $8 \mathrm{pm}$ from http://www.academicjournals.org/ER2tringer.

[6] Alexander, D. (2002). Principles of Emergency Planning and Harpenden Terra Publishing: London.

[7] AMREF. (2005). Improving School Sanitation and Hygiene in Kenya. Net as Kenya: Nairobi.

[8] Anyuor, N. \& Weru, J. (May 2010 19th). Search for bodies of flood victims. Nairobi: Standard newspapers Ltd.

[9] Arson control forum, (2006). Surveys of School Fires, Research bulletin Number 10.

[10] Ary, D. (2006). Introduction to Research in Education. Canada: Vicki Knight.

[11] Asian Disaster Preparedness Center (2008). A study on Impact of Disasters on the Education Sector in Cambodia, Bangkok: ADPC.

[12] Baltas, E. (2004). Safety of School Buildings in Greece, in OECD (2004), Lessons in Danger, International Conference on School Safety and Security, Paris, 12-14 November 2003.

[13] Blackaby, S. (2007). Fire safety education school [Online] Retrieved from http://www.esfrs.org/community_safety/Schools/schools.htm\#secondary[20 09, August 8]

[14] Brown, J. (1999). Doom, Quake and Mass Murder.dir.salon.com/topics.

[15] Burger, L. (2000). Background and Rationale to School Sanitation and Hygiene Education School Sanitation and Health Education. UNICEF, New York

[16] Calefati, J. (2009). School Safety 10 years after Columbine high school shooting. U.S. News and World Report

[17] Cavanagh, S. (2004). Schools abroad brace against terrorism. Education week, Nairobi.

[18] Chukwu, E.C. (2008). School safety and security: A Management challenge to principals in the Vryheid District. Published Master of philosophy thesis, University of Johannesburg.

[19] Cooper, M.A. (1995). Emergent Care of Lighting and Electrical Injuries. Seminars in Neurology Vol.15 No. 3: 268 - 278.

[20] Dankit, K. Nassiuma (2017). An Introduction to Statistical Methods for Information Analysis. Utafiti Foundation, Eldoret

[21] Denscombe, M. (2007). The Good Research Guide: For Small-Scale Social Research Projects. Berkshire: Open University Press.

[22] FAWE, (2001).Creating an Enabling Environment for Girls in School. The News Magazine about the Education of Girls and Women in Africa Vol.9 (1) January - March 2001. Nairobi: FAWE.
[23] Fire Administration National Fire Data Centre, (2007). Safety Issues, safety Articles, products, safety tips, safety issues, community and forums. www.safety issues.com accessed on 28th December, 2017 at 10.30pm.

[24] Gaitho, M. (2001), July 30th). The Plight of Head teachers: Running Schools with little funds. Daily Nation Nairobi: Nation Media.

[25] Gicheru, C. (1998, March 28). These disasters can be averted. Daily Nation, Nairobi:

[26] Nation Media Group.

[27] Government of Kenya, (2008). Sector Plan for Environment, Water and Sanitation: 2008 -2012. Nairobi: Environment, Water and Sanitation Sector.

[28] Government of Kenya, (2009).National School Health and Policy. www.health.go.ke.Retrieved on 10/11/2017 at 9pm.

[29] Hirano, S. (2009). Child friendly Schools and Infrastructure. Rwanda Ministry of Education. Kigali.

[30] Hossein, I. \& Izadkhan (2006). Fire Safety Training: Its importance in enhancing Fire Safety Knowledge and Response to Fire. The Australian Journal of Emergency Management, Vol. 21 No.4

[31] Huck, S. (2000). Reading Statistics and Research. New York; Addison Wesley Longman. Inc.

[32] Ians, N. (2010). 1,200 Delhi Schools Lack Fire Safety Measures. Delhi: Ht Media Ltd International Finance Corporation (2010). Disaster and Emergency Preparedness. Guidance for Schools. Washington D.C.

[33] INEE (2012). Inter Agency Network for Education in Emergencies. UN Plaza, New York. USA.

[34] ISDR (2002). Living with Risk: A Global Review of Disaster Reduction Initiatives. United Nations, Geneva, Switzerland, Karanja F.K, Mutua F.M, editors (2000). Reducing the impact of Environmental Emergencies through early warning and preparedness.

[35] ISDR (2010). Review of 8 MDGs' relevance for disaster risk reduction and vice - versa, http://www.unisdr.org/eng/mdgs-drr/review-8mdgs.htm.

[36] Karanja, F. \& Mutua, F.M. (2000). Reducing the impact of environmental emergencies through early warning and preparedness. www.unu.edu/env/govern/ElNino/Country Reports/pdf/kenya.pdf.

[37] Kasumba, M. (2004). How war on swamp fever was executed. East African Standard, Nairobi; The Standard Media Group.

[38] Keith, F. (2009). Introduction to Research Methods in Education. Thousand Oaks: Sage Publication. Kenya Red Cross S.

[39] Kenya Red Cross Society, (2000). Alleviating Human Suffering. Information Bulletin No. 2/2000; 1-20. Kenya Red Cross.

[40] Kombo, D.K. \& Tromp, D.L.A. (2006). Proposal and Thesis Writing: An Introduction. Nairobi: Paulines Publication Africa.

[41] Krathwohl, D. (2004). Methods of Education and Social Science Research: An Integrated Approach. Long Grove: Waveland.

[42] Lindonde, R. (2004). Sealing up school sanitation and hygiene promotion and gender concern, paper presented at the school sanitation and hygiene education symposium, June 8 -10, 2004.

[43] Lucheli, O. (2009). School Disaster Preparedness Poor. Nairobi Standard Digital.

[44] Lulua, L. (2004). Addressing School Safety in Uganda. Kampala: UPHOLDUSAID.

[45] Luvega, C.I. (2007). An Evaluation of Free Primary Education Policy in Selected Primary Schools in Kakamega District. Unpublished Masters Thesis. Maseno University.

[46] Makabila, S., Ayodo, H. \& Ringa, M. (2006). Putting out school fires. The Standard. Nairobi: Standard Media Group.P.5

[47] Makhanu, F.N. (2009). Disaster Preparedness as a Remedy to Fire Disasters in Learning Institutions of Kenya Centre for Disaster Management and Humanitarian Assistance. Unpublished Thesis, Masinde Muliro University of Science and Technology

[48] Mburu, M. (2012). Factors Influencing the Implementation of Safety Standards in Secondary Schools in Limuru District, Kiambu County, Kenya. Unpublished Masters Project: University of Nairobi.

[49] McNabb, C. (2009). Descriptive Research Methodologies. Retrieved on $2 / 10 / 2017 \quad$ at $1 \mathrm{pm}$ from http://www.docstoc.com/docs/17400982/Descriptive-ResearchMethodologies.

[50] Maoulidi, M. (2005). Education needs assessment for Kisumu City, Kenya Columbia Earth University: Millennium Cities Initiatives. 
[51] Miles, B.M. \& Huberman, A.M. (1994). Qualitative Data Analysis. A Method Resource Book. College Press.

[52] MOE (2008). Safety and Standard Manual for Schools in Kenya (1st Edition). Nairobi; MoE Republic of Kenya.

[53] MOE, (2012). Nepal Education in Figures 2012 at a Glance. Ministry of Education, Government of Nepal: Kathmandu, Nepal. P. 23

[54] MOEST, (2011). A report of the task force on student discipline and unrest in secondary schools. Nairobi: Jomo Kenyatta Foundation.

[55] Mugenda, O.M. \& Mugenda, A.G. (2003). Research Methods: Quantitative and Qualitative Approaches. Nairobi: Acts Press.

[56] Muzaffargarh (2010). Pakistan: Flood Damaged Schools Lead to Education Worries www.Irinnews.org.

[57] NACADA (2002). Drug and Substance Abuse: The Kenyan Context. Nairobi: NACADA News.

[58] Nafula, N.N. (2002). Achieving Sustainable Universal Primary Education through Debt Relief. The Case of Kenya. Discussion Paper no. 2002/66, KIPPRA, Nairobi. KIPPRA.

[59] Nakitto, M. \& Lett, R. (2012). The Preparedness of Ugandan schools for fires. Makerere: Makerere Medical School.

[60] Nathe S.K. (2000). Public education for earthquake hazards. Natural Hazards Review, November; p. 191-196.

[61] National Centre for Education Statistics. (1995). "Student strategies to avoid harm at school" (Washington DC: US. Department of Education, October 1995), NCES 95-203.

[62] NCEF (2008). Earthquakes and Schools. U.S. Department of Education, Office of safe and Drug-free schools www.Ncef.or

[63] Nderitu, C. (2009). Implementation of Safety Standards Guidelines in Secondary Schools in Githunguri Division, Kiambu District. Unpublished Project, Kenyatta University.

[64] Ndirangu, L., Ocharo, M. \& Njoka, J. (2006).Vulnerability of Kenyan Schools to Disaster:

[65] A Case of Nairobi Public Secondary Schools, Unpublished M.Ed project,

[66] University of Nairobi.

[67] Ngecu, W.M., \& Mathu, E.M. (1999). The El-Nino- triggered landslides and their socio economic impact on Kenya. Environmental Geology 38:277-284.

[68] Odalo, B. (2001). Sixty eight dead. Daily Nation. Nairobi: Nation Media Group. Pp.1.

[69] Oduor, A. (2012).Tragedy Relieves Memory of Dormitory Deaths. [Online] Retrieved from Standard Digital News. Available at standardmedia.co.ke/?article ID=2000064691 \& page No. [2012, May 10].

[70] Okumu, M.A. (2014). Perceptions on Opportunities and Challenges for Public Secondary School Principals in the Implementation of Selected Safety Policy Guidelines in Kisumu West District, Kenya. Unpublished Thesis. Maseno University.

[71] Oranusi, et, al. (2007). Food Safety Evaluation in Boarding Schools in Zairia, Nigeria using the HACCP systems. Scientific Research Essay Vol.2 (10): 326-443.

[72] Oriang, L. (2001). Taking Charge of the welfare of our children. Daily Nation Nairobi: Nation Media Group.

[73] Otula, P.A. (2007). Mastery of Modern School Administration. Education Media: Nairobi.

[74] Orido, G. (2010). A different kind of theatre for action of a unique sort. www.standardmedia.co.ke.

[75] Orodho, J.A. (2003). Techniques of Writing Research Proposals and Report in Educational and Social Sciences. 1st ed. Nairobi: Masola Publishers.

[76] Ombati, C. (2012). Six Die in Dormitory Fire in Nairobi. [Online] Retrieved from Standard Digital News. Available at standardmedia.co.ke/?article $\mathrm{ID}=2000067677$ \& story .title=six=die=in=dormitory=fire=in=Nairobi

[77] Omollo, O.D. (2011). An Assessment of the Implementation of Safety Policies in Public Secondary Schools in Kisumu West and East Districts. Unpublished Masters Thesis, Maseno University.

[78] Omolo, O. \& Simatwa, E.M.W. (2010). An Assessment of the Implementation of Safety Policies in Public Secondary Schools in Kisumu East and West District, Kenya Educational Research (ISSN: 2141-5161). Vol.1 (11).

[79] Onyango, M. (2008). Factors Influencing Participation Rates In Public Primary Schools In Rangwe Division of Homa-Bay District, Kenya. M. Ed project, University of Nairobi.
[80] Oriang' L (2001). Taking charge of the welfare of our children. Daily Nation, p. 5.

[81] Pandhal, S. (2005). Knowledge, Attitude and Practices of Oral Health Among Twelve Year Old Children Attending Urban Primary Schools in Kisuumu City. Unpublished Masters Thesis, Maseno University.

[82] Park,S., Kwak, T. \& Chang, H. (2010). Evaluation of Food safety training for food handlers in restaurant operations. The Korean Nutrition society and Korean Society of Community Nutrition. Downloaded 29th December, 2017

[83] Patkus, B.L. \& Walpole, M.A. (2007). Disaster Planning for Cultural Institutions. American Association for state and Local History. Nashville.

[84] Ramani, K. (2003, November, 29th). Education talks herald changes. East African Standard Nairobi: The Standard Media Group p.1.

[85] Ratemo, J. (2007, September 19). New Study claims Laboratory Assistants have died from Exposure to Harmful Chemicals. The Standard Nairobi; Standard Media Group.

[86] Redican, K., Olsen, L. \& Baffi, C. (1993). Organization of School Health Programs. Brown \& Benchmark, Madison.

[87] Reuters (2004). Indian School Fire Kills 90 Children. Retrieved on 24Th December, 2017 from http://www.wsws.org/articles/2017/ken-m30.shtml.

[88] Republic of Kenya, (2008). Safety Standard Manual for Schools in Kenya. Nairobi: S.R 54/2007.Government Printers

[89] Republic of Kenya, (2001). Education Sector Reforms Action Plan 2001 2005. Policy Options, Nairobi: Government Printer

[90] Republic of Pakistan. (2003). Draft Guidelines for Education Sector ERWG [Online].

[91] Retrieved from: http://floods2010.pakresponse.info/ [2018, Sept 27]

[92] Rocha,V. (2001). Ensuring Girls Safety in Schools. Retrieved on 28th December, 2017 at 11 pm from www, girls' safety.org

[93] Roeder, W.P. (2003). Lighting Safety: It could Save your life. Observer The Magazine for Air force Weather, July - August 03, 32 - 33.

[94] Ronan, K.R. (1997). The effects of a "benign" disaster: symptoms of posttraumatic stress in children following a series of volcanic eruptions. Australas J Disaster Trauma Stud. [cited 2013 Jan 3]. Available from: http://trauma.massey.ac.nz/issues/1997-1/ronan1.htm.

[95] Ronan, K. et, al. (2010). Correlates of Hazards Education for youth: A replication study. Nat Hazards. 53:503-526. Doi: 10.1007/s11069-009-94446.

[96] Ronan, K.R. \& Johnston, D.M. (2001). Correlates of hazards education programs for youth. Risk Anal. 21:1055-1063.

[97] Ronan, K.R. \& Johnston, D.M. (2003). Hazards education for youth: a quasiexperimental investigation. Risk Anal. 23:1009-1020.

[98] Rowan, D. (2001). Kenya: School Fire Kills at Least 59 Students. Retrieved on 11th November, 2017 from http;//www.wsws.org/articles/ken-m30.shtml

[99] Sagara, R.K. (2012). Impact of Occupational Stress on Head Teachers' Tasks in Secondary Schools of Kisumu County, Kenya. Nairobi; Unpublished Master's Thesis Kenyatta University, Kenya.

[100]Savula, A. \& Atsiaya, P. (2004). Grilles order to school heads. The Standard p.4. Nairobi: Standard Group.

[101] Shaw, R. et, al. (2004). Linking experience, education, perception and earthquake preparedness. Disaster Prev Manage. 13(1):39-49.

[102] Shaw, M. (2002). Promoting Safety in schools: International experiences and actions. Crime prevention series No.3 Bureau of justice Assistance Monograph Washington, DC. United States Department of Justice.

[103] Shiwaku, K.et al. (2007). Future perspective of school disaster education in Nepal. Disaster Prev Manage. 16(4):576-587.

[104]Simatwa, E.M.W. (2007). Management of Student Discipline in Secondary schools in Bungoma District, Kenya." Unpublished Ph.D Thesis, Maseno University.

[105]Spencer, R.W. (2010). What causes Lighting National Weather Service. Office of Climate, Water and Weather Services Silver Spring.

[106]Teachernet, Fire Safety Area. (2007). Building Bulletin 100, Design for fire safety in schools. (http://www.teachernet.gov.uk/mngt/re).

[107]Toili, W.W. (2001). Impact of Environmental Education on Secondary School Students' Perspectives of Environmental Quality in Bungoma District. Unpublished PHD thesis, Maseno University.

[108]Tuckmaan B.W. (1994). Conducting Educational Research (5th ed.) Ohio State University. Harcourt Brace College Publishers. 
[109]UNESCO, UNICEF. (2012). Disaster risk reduction in school curricula: case studies from thirty countries. United Nations Educational, Scientific and Cultural Organization and United Nations Children's Fund; Geneva, Switzerland. 208

[110]UNESCO (2007). Challenges of Implementing Free Primary Education in Kenya. Assessment Report. Nairobi: UNESCO

[111]UNICEF (2000).Global Water Supply and Sanitation Assessment Report. http;//www.who.int/doc.store/water/sanitation.healthGlobassesment/globa. Retrieved 30th December, 2017.

[112]UNICEF (2007). Kenyan School Children face Challenges LeftBy Recent Floods. UNICEF; Nairobi.

[113]UNISDR. (2004). Hyogo framework for action 2005-2015.United Nations Inter-Agency Secretariat of the International Strategy for Disaster Reduction; Geneva, Switzerland.

[114]UNISDR. (2007). Towards a culture of prevention: disaster risk reduction begins at school - good practices and lessons learned. United Nations International Strategy for Disaster Reduction; Geneva, Switzerland. p. 143.

[115] UNISDR. (2011). Compilation of national progress reports on the implementation of the hyogo framework for action. HFA Priority 3, Core Indicator 3.2; Geneva, Switzerland. Available from: http://www.preventionweb.net/english/hyogo/framework/progress/

[116]UNDP. (2008). National strategy for disaster risk management in Nepal. Kathmandu: MoHA, UNDP, EC, NSET; [cited 2012 Nov 13]. Available from: http://www.undp.org.np/pdf/NSDRMFinalDraft.pdf

[117]USDE, (2004).United States Education Department.

[118]USFDA (2008). Sanitation starts with physical facilities, US Public Health Service Food and Drug Administration.

[119] Veerashetcharappa, (2005). Community Contribution for Environmental Sanitation in the Rural Area Myth or Reality, India.
[120]Wachira et al (2011). Impact of Free Primary Education on Management of Schools in Embu District. International Journal of Business, Humanities and Technology Vol. 1 issue 2.

[121] Wedgwood, R. (2005). Post-Basic Education and Poverty in Tanzania. PostBasic Education and Training Working Pay: Series- No.1. Center of African Studies. University of Edinburgh.

[122]Wendo, B. (2002). Mudslides in Kenya. Nairobi: Daily Nation, April 16th 2002, pg 8

[123]WHO. (2009). Draft Wash Standards in Schools in Low-Cost Settings. http;//go.worldbank/org/OBRO8PH70/ retrieved on 28th December, 2017 at $11 \mathrm{pm}$.

[124]World Health Organization. (2005). Global Status Report on Road Safety: A Time for Action. Geneva: Switzerland: WHO.

\section{AUTHORS}

First Author - Pamela Ananda - Faculty of Education, Tom Mboya University.

Second Author - Prof. Enose M.W.Simatwa - Faculty of Education, Tom Mboya University.

Third Author - Dr. Stella Juma - Faculty of Education, Rongo University. 